\title{
ウイズコロナ時代の人間ドック健診
}

〜医療技術室長及びフロア管理者の立場から〜

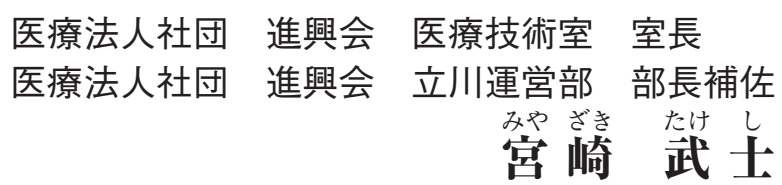

進興会 立川北口健診館

丸山 弘美、浅野 昌也、藤田 貢、小倉 順子

今井 俊一、石垣 洋子、古川 恭士、森山 紀之

\section{【目 的】}

未曽有のコロナ禍を迎え、人間ドック健診は精度を保ち、安全性をより考慮した感染予防と感染疑 い受診者発見時には適切かつ迅速に、行政・指定医療機関への誘導が必須となる。

\section{【対 象】}

2020年 6 月から 8 月末 立川北口健診館・オーバルコート検診クリニックドック受診者 3,582名 （立川） 1,269名（オーバル）胸部 CT 受診者２82名（立川） 355名（オーバル）

\section{【方 法】}

当会コメデイカル運営部門（医療技術室）で作成したコロナ発見時の対策フローを報告し、数名の 無症状肺炎像（胸部 CT 検診）を有した受診者への緊急対応（初動、連絡、隔離、消毒、指定医療機 関紹介）が適切であったかについて報告する。

\section{【結 果】}

フロー使用により、隔離、受診者説明（医師）、スタッフ連絡、消毒、行政・指定医療機関紹介が円 滑に対処でき、他受診者への影響もなかった。後日報告にて該当者 PCR 陰性。

\section{【結 語】}

当会人間ドックコロナ対策を報告した。当会では医療技術室より各施設へ横串連携、情報の一元化 共有を行い、適切・迅速な受診者対応、隔離、消毒、接触者把握、PCR 陽性時のスタッフ院内 PCR 検 査誘導、メンタルフォローを独自施行しているが、不十分な部分も多く、貴重なアドバイスをいただ けましたら幸いです。 